\title{
Paul's 'former conduct in the Judean way of Life' (GAL 1:13) ... OR NOT?
}

\section{Author:}

Markus Cromhout ${ }^{1}$

\section{Affiliation:}

${ }^{1}$ Faculty of Theology, University of Pretoria, South Africa

\section{Correspondence to:}

Markus Cromhout

e-mail:

mcromhout@nac-sea.org.za

Postal address:

P O Box 1078, Sunninghill,

2157, South Africa

\section{Keywords:}

Paul; Galatians; New

Testament; hermeneutics;

Jewishness

\section{Dates:}

Received: 10 Nov. 2008

Accepted: 31 Dec. 2008

Published: 01 July 2009

How to cite this article: Cromhout, M., 2009, 'Paul's "former conduct in the Judean way of life" (Gal 1:13)...or not?' HTS Teologiese Studies/Theological Studies 65(1), Art. \#127, 12 pages. DOI: 10.4102/hts.v65i1.127

\section{This article is available} at: http://www.hts.org.za

\section{Notes:}

Dr Markus Cromhout participates as research associate in the project 'Biblical Theology and Hermeneutics', directed by Prof. Andries G. van Aarde Honorary Professor of the Faculty of Theology at the University of Pretoria, South Africa.

\section{(c) 2009. The Authors.} Licensee: OpenJournals Publishing. This work is licensed under the Creative Commons Attribution License.

\section{ABSTRACT}

Various arguments are made about Paul's 'Jewishness/ Judeanness' as a follower of Jesus Messiah, for example, that Paul essentially remained to be 'Jewish/Judean' and that he still fully operated in the world of 'Judaism'. These claims are investigated by answering three sets of questions derived from a proposed general model of ethnicity, which is developed with the help of cultural anthropology (ethnicity theory).

\section{INTRODUCTION}

Recently, Biblical Interpretation basically devoted almost an entire issue to investigating Paul and the matter of his 'Jewishness'. What is at stake? Considering the legacy of anti-Semitism and strained Christian-Jewish relations, various arguments are proposed aimed at salvaging Paul's own 'Jewishness' (as opposed to it being entirely superseded by a new 'Christian' identity) and interpreting him as still operating fully in the world of 'Judaism'. Pauline scholarship, even in the form of the new perspective, it is argued, does not promote Jewish-Christian relations. To salvage Paul's own 'Jewishness' is, therefore, to promote dialogue between Jews and Christians, at the same time avoiding essentialist definitions of Judaism and Christianity which make them mutually exclusive (i.e. Judaism as observance of the Torah versus Christianity as devotion to Christ). This is also to safeguard the inherent value of 'Jewishness', to regard Paul's polemic as 'intra-Jewish', as well as to absolve Paul of spearheading 'anti-Judaism' (Eisenbaum 2005; Nanos 2005; Setzer 2005; cf. Malina 2002). Campbell proposes, even after Paul's 'conversion', that Paul's identity was basically 'Jewish', as Paul sought to show that the Christ event and movement was consistent with 'Judaism', and the Christ movement still operated under the umbrella of 'Judaism':

There was no conception as yet of a new religion springing up in opposition to Judaism ... Increasingly ... it is being recognised that what Paul asserted was the relativisation in Christ of all aspects of a person's life, not the elimination or obliteration of one's particularity.

(Campbell 2005:300, 306-307)

Eisenbaum (2005) also makes a plea that we stop referring to Paul as a 'Christian' - Paul does not use this essentialist category himself - and this tends to make claims to Paul's 'Jewishness' confusing at best, impossible at worst. In order to save Paul's 'Judeanness' (a term I prefer), Johnson Hodge (2005) proposes that ethnic identity be regarded not as monolithic and fixed, but as multi-faceted and flexible (cf. Buell and Johnson Hodge 2004). Paul also had multiple identities and, apart from his traditional Judean identity ( $c f$. Rom 11:1; Phil 3:5-6), he received two more components: Paul is 'in Christ' and, secondly, was called to be an apostle to the Gentiles (Gal 1:16). In a hierarchy of nested identities, being 'in Christ' was his primary identity. However, Paul's 'dying to the Law' (Gal 2:19) does not equate to his rejection of the Law. Paul reprioritised other facets of his identity, or he was adaptable in order to interact with Gentiles and live 'gentilelishly', which refers to his eating with Gentiles and his willingness to forego circumcision for them. This is how, Johnson Hodge suggests, Galatians 2:19, 1 Corinthians 9:19-22 and Philippians 3:7-9 must be understood. Indeed, Paul remained to be Torah observant and, when eating with Gentiles, the food could have satisfied Judean dietary and purity norms. Overall, these multiple and nested identities, as well as Paul's adaptability, do not mean that Paul gave up his identity as a Ioudaios (his 'Judeanness') to become a Gentile or 'Christian'. Paul and the Gentiles share being 'in Christ', but they remain distinguished ethnically. In a similar way Nanos (2005:267) suggests 'Paul and other early believers in Jesus were Jewish and probably understood what they were doing to be Judaism', and were 'engaged in a temporary task on behalf of Israel, and not founding a new religion or sect that was in some way less Jewish.'

For our purposes the following four features of the views outlined above are of interest: (1) It is asserted that Paul, even after his encounter with the risen Messiah, essentially remained Judean ('Jewish'); (2) Paul still operated in the world of Judeanism ('Judaism'), even remaining Torah observant; (3) Paul did not establish a new religion/culture; and (4) Judeans and Gentiles in Messiah ('in Christ') remained distinguished ethnically, and Paul encouraged the relativisation of cultural phenomena.Various questions arise from this. How authentic are these proposed features of Paul's? In particular, what is Paul's understanding of his own Israelite identity or 'Judeanness' and the kind of Judeanism, or

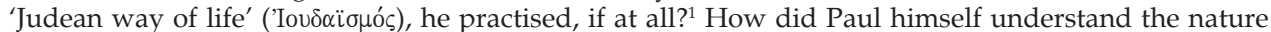
of the Messianist movement to which he belonged? How, according to Paul himself, should Judeans and Gentiles relate to one another? In other words, this article attempts to facilitate an emic description of Paul (cf. Harris 1976). However, there is a potential pitfall. Although Paul's letters are available, the reader is not in a position to pose the question: 'Paul, what do you mean by this', or to conduct a personal interview and get clarity on issues that lend themselves to differing interpretations. We

1.In a recent article, Elliott (2007) forcefully argued that the appropriate translation for 'Iovő̂ioç is 'Judaean' and not 'Jew'. Elliot further argued that one should rather use the preferred insider (emic) nomenclature of self-identification ('Israel(ites)', 'House/children of Israel'). In a similar manner Elliott argued that scholars must eliminate the widespread use of "Judaism" (the usual transliteration of 'Ioudo "øó altogether, as that was not a ustomary term of self-identification.' '. using 'Judaism' "Joday a a collective term for Judaeans around the altoge the the usage of 'Judeanism' (cf. BDAG 2000) is also implicated as unwarranted. However, I would argue that it could still be used; bearing in mind that it defines a mode of behaviour, and not a social grouping as such. 
are somewhat limited by the act of 'subjective' interpretation, to identify general patterns, and to salvage what we think or interpret to be Paul's own view on matters.

The approach taken below will be to give a 'snapshot' overview of Paul's 'authentic' letters in order to answer these questions. This approach is used because of limited space but is also deliberate, as we want to avoid emphasising some passages while neglecting to mention others.

It also needs to be explained that the questions posed above will be answered via an indirect route. In the course of this investigation we will be guided by the insights of ethnicity theory, part of the rich enterprise of cultural or social anthropology. Rather than answering these questions about Paul through the lens of personal theological or ideological agendas (and so also give predominantly etic descriptions) - which could distort Paul to a greater or lesser degree - we will ask another set of appropriate questions derived from ethnicity theory, and, hopefully, in this way obtain more appropriate answers. Underlying this investigation is the conviction that first-century '(House of) Israel' must be understood and approached as an ethnic identity (cf. Stegemann 2006; Esler 2006:27).

\section{A GENERAL MODEL OF ETHNICITY}

Ethnicity theorists have long grappled with the reality of ethnic identity in the modern world and since the 1960s it has become a burgeoning enterprise as a field of study. Research is being done on ethnic affiliation and conflict in an attempt to understand the dynamics behind it, and to suggest how ethnic conflict can be avoided and co-existence can be accommodated (Horowitz 1985). However, a word of caution is required here. Using ethnicity theory is a potential minefield in that the greater part of it has been characterised by claims about the subject that were regarded as being mutually exclusive. Is ethnicity primordial or, rather, constructionist, circumstantial, situational or instrumental $?^{2}$ Many theorists have argued for a combination of the various models as none of them alone seem to suffice in explaining ethnicity, a view that will also be used here ( $c f$. Cromhout 2007:87-88)

Apart from the difference in theoretical perspectives, the insights offered by ethnicity theory are certainly relevant to New Testament studies. What we understand as ethnic groups today, also existed during the first century, if not since humankind first decided to group together in more or less permanent settlements (cf. Duling 2005:127-29; Esler 2003a:53; Smith 1986:32-46; 1997). However, what is ethnicity? There is no universal definition available and the issue is much debated, although there is a degree of overlap when reviewing definitions or approaches of some ethnicity theorists ( $c f$. Cromhout 2007:82). The following working model of ethnicity (or 'ethnic identity') is offered without claiming that it is original or represents a consensus view, as something like that, at least for the moment, does not exist. It is also not suggested that the model is comprehensive, definitive or final, but it attempts to bring together some of ethnicity theory's most salient features. The model of Jenkins $(1997: 165)^{3}$ is used in this study and provides the backbone to

\footnotetext{
2.Primordialism, which emphasises the view of how social actors themselves perceive reality, argues that ethnic groups are held together by 'natural affections'. Ties of reality, argues that exp blood, language and cultu they are seen as natyr. Concrivtive is fluid, freely chosen, and continually reconstructed. The emphasis shifted away from the cultural contents of ethnic groups to how and why ethnic groups create an maintain their group boundaries. The 'circumstantial' approach sees ethnic identity as important in some contexts but not in others. The identity remains constant, but circumstances dictate if it should be of special importance. The 'situational' perspective claims that identity is expressed in different ways as the social situations of the individual change. 'Instrumentalists' argue that an ethnic identity is intentionally mobilised for material or political ends (Fenton 2003:84). What sets all these approaches apart from primordialism is the element of choice on the part of the social agents in question. Sometimes some of these terms are used interchangeably, since 'instrumental' and 'situational' models are treated as part of the 'circumstantial' 'proach (Scott 1990:148), or 'instrumentalism' (it is said) is sometimes referred to as the 'circumstantialist' approach (Banks 1996:39).
}

the approach taken here. The model is 'fleshed out', however, with other insights in an attempt to make it more user friendly. It invites critique and modification, but as a starting point the working model of ethnicity looks as follows:

1. Ethnicity is a form of social identity and relation, referring to a group of people who ascribe to themselves and/or by others, a sense of belonging and a shared cultural tradition.

2 Ethnicity is socially (re)constructed, the outcome of enculturation and socialisation, as well as the social interaction with 'others' across the ethnic boundary.

3. Ethnicity is about cultural differentiation, involving the communication of similarity vis-à-vis co-ethnics (aggregative ' $w e^{\prime}$ ) and the communication of difference in opposition to ethnic others (oppositional 'we-they').

4. Ethnicity is concerned with culture - shared meaning - which consists of any combination of the following: widely accepted values/norms which govern behaviour, a corporate name for the group, myths of common ancestry, shared 'historical' memories, common phenotypical or genetic features, an actual or symbolic attachment to a specific territory or ancestral land, a shared language or dialect, kinship patterns, shared customs, and a shared religion. ${ }^{4}$

5. Ethnicity is no more fixed than the culture of which it is a component or the situations in which it is produced and reproduced. ${ }^{5}$

6. Ethnicity is both collective and individual, externalised in social interaction and internalised in personal self-identification.

The last two points of Jenkins's model are left unaltered. Having set out this model we are in a better position to ask appropriate questions and obtain more appropriate answers about Paul and the issue of his Israelite identity. The following questions are extrapolated from the above model as being relevant to our purposes here:

1. Did Paul feel a sense of belonging with regard to fellow Israelites? Did he internalise his ethnicity in personal selfidentification?

2. How much did Paul share in the 'Judean way of life', the Israelite cultural tradition, or its aspects of shared meaning?

3. How did Paul communicate his ethnic identity (i.e. his similarity or difference)? Did he externalise his ethnicity in social interaction?

Using the questions posed here is a different way to approach old problems. Let us proceed now to answer these questions.

\section{PAUL'S ISRAELITE ETHNIC IDENTITY: A 'SNAPSHOT' OVERVIEW}

\section{Did Paul feel a sense of belonging with regard to fellow Israelites? Did he internalise his ethnicity in personal self-identification?}

Belonging to an ethnic group is like belonging to a form of extended kinship. Horowitz (1985:81) draws attention to the needs served by ethnicity, which are similar to those of kinship: familiarity and community, family-like ties to counter isolation in complex societies, emotional support and reciprocal help, and mediation and dispute resolution. As opposed to kinship, ethnicity meets these needs across a larger canvas. Theissen (1992:216-19, 274-76) refers to the strong sense of solidarity

3.Jenkins proposes a 'basic social anthropological model' of ethnicity, which he presents as a set of loosely linked propositions as follows:

- Ethnicity is about cultural differentiation (bearing in mind that identity is always a dialectic between similarity and difference).

- Ethnicity is concerned with culture - shared meaning - but it is also rooted in and the outcome of, social interaction.

Ethnicity is no more fixed than the culture of which it is a component, or the situations in which it is produced and reproduced.

- Ethnicity is both collective and individual, externalised in social interaction and internalised in personal self-identification.

4ot all of these features are needed for a particular ethnic group. The most widespread of these features are kinship relations and myths of common ancestry, while some connection with a homeland is not far behind (Duling 2005:127; cf. Esler 2003a:44; Hall 2002:9-10; Miller 2008:175).

5 Refer to footnote 
among the 'Jews', which extends across political boundaries and is enhanced by what he calls 'supraregional communication'. This solidarity is also recognised by outsiders (e.g. Tacitus, Hist. 5.5.1).

We need to investigate Paul's sense of belonging to Israel along the 'cognitive', 'evaluative' and 'emotional' dimensions of group identity and membership brought to our attention by Esler (1996:226-227), who himself drew on the work of Henri Tajfel $(1978 ; 1981)$. This relates closely to the aspect of Paul's personal self-identification. The 'cognitive' dimension is the recognition of belonging to a group; the 'evaluative' dimension relates to the positive or negative connotations of belonging to a group, while the 'emotional' dimension has to do with attitudes towards insiders and outsiders. Also related to this is the matter of 'stereotyping', albeit negative stereotyping of the 'out-group' or positive stereotyping of the 'in-group'.

We will begin with the cognitive dimension. Paul refers to Israelites as his 'own people/kinsmen' ( $\gamma$ '́vo's Gal 1:14; 2 Cor 11:26), which corresponds to Philippians 3:5 where Paul describes

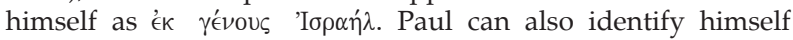
variously as 'Hebrew', 'Israelite', 'of the tribe of Benjamin', and descendant of Abraham in 2 Cor 11:22 and Phil 3:5-6. This is traditional 'insider' language, where Paul the Israelite, when it suits his purposes, identifies himself or addresses fellow Israelites as 'insiders'. Alternatively, Paul would also identify himself as

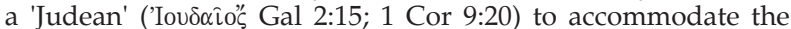
Gentile addressees or to use 'traditional we-they language and antithesis to proclaim an overcoming of traditional distinctions and discriminations in the new inclusive messianic community' (Elliott 2007:144; see 141-46).

Yet Paul is not one who puts 'confidence in the flesh' (Phil 3:3), i.e. in his Israelite/Judean identity and his status of being circumcised. To whom does Paul feel a sense of belonging then? It becomes clear that Paul sees himself in one respect as belonging to a group distinct from both the Israelites and the Gentiles. Paul describes believers as embedded in a different group, a fictive family, the 'body of Messiah' (1 Cor 10:17; 12:13-14, 20; cf. Eph $3: 6)$ or, alternatively, as the 'congregation of God' (Gal 1:13; 1 Cor 10:32, 15:9; cf. Phil 3:6), or the 'household of faith' (Gal 6:10). Paul also refers to believers as children and brothers (Gal 4:19; 1 Cor $4: 14 ; 2$ Cor $6: 13 ; 12: 14)$. They, like Jesus, call on God as 'Abba' (Gal 4:6). This new sense of belonging was initiated by immersion. In Galatians 3:27-28 Paul states those 'immersed into Messiah' have 'put on Messiah', and 'there is neither Judean nor Hellene ... you are all one in Messiah Jesus.' The initiatory rite of baptism/immersion, therefore, included the dimension of entering a new group, 'being in Messiah', which at the same time involved the breaking down of social barriers for all those who participated therein ( $c f$. MacDonald 1999:240).

We can also see that Paul's argument is that being 'in Messiah' is not a Judean identity (pace Buell and Johnson Hodge 2004:24749). Ideally, ethnic particularity does not remain, especially in Galatians. ${ }^{6}$ What Paul does, however, is to claim the title 'Israel' with its inheritance for those who are in Messiah (pace Campbell 2005:310). Paul himself calls this the 'Israel of God' (Gal 6:16) which, for now, is distinct from 'Israel according to the flesh' (1 Cor 10:18). For Paul, the 'Israel of God' - which can be described, for lack of a better description, as faith Israel - is a new kind of ethnos (Setzer 2005:292-93, 295). Both Israelite and Gentile believers embody a new and third grouping over and above traditional Israelites and Gentiles. In 1 Cor 1:22-24 Paul distinguishes between Judeans, Hellenes and 'those who are called'. In a similar manner Paul distinguishes the 'єкК $\lambda \eta \sigma i \alpha$

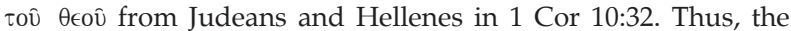
followers of the Messiah appear as a new or third audience

6.Since the covenant of circumcision is in the background (cf. Martin 2003) and only relevant to Israelite males, and points to Israelite identity as such, the irrelevance of circumcision - which appears to be the force of Paul's argument here - points to the irrelevance of ethnic distinctions. This is a view that Paul modifies in Romans.
(Taylor 2002:752). According to Esler Paul's language in Gal 3:28 and 6:15-16 meant:

there was now to be a new social and religious entity on the scene. Paul unambiguously asserts that the Christ followers constituted a third group, set over and against both the Judaic and the gentile worlds.

(Esler 1998:89)

Whether a new 'religious entity' was on the scene for Paul is not particularly clear, and it is perhaps better to say that Paul helped to establish and belonged to a new kinship, a new ethnos (1 Cor 12:13; 15:31; Phil 3:3; Gal 2:19; cf. 6:14).

In Paul's letter to the Romans, we encounter a Paul who is similar, yet somehow different in his approach. He consistently identifies himself as an Israelite/Judean in a positive way (Rom $9: 1-5,24 ; 10: 1-2 ; 11: 1)$ and does not dismiss that identity as irrelevant or meaningless as in 2 Cor 11:22-12:1 and Phil 3:5-8. But yet again we find Paul's language of belonging to an ethnos distinct from traditional Israel. According to Paul, the authentic Judean is one 'inwardly', with a heart circumcised by the Spirit, and he distances himself from the traditional identity marker of circumcision in the flesh (Rom 2:28-29). Here Paul redefines the boundaries of the 'authentic' Israel. What Paul is actually doing is scooping all of non-believing Israel up and placing them outside the boundary of 'Israel' as now conceived by him (Rom 9:6-7). Within the boundary of the 'authentic' Israel, however, are the remnants of Judeans who will be saved (Rom 9:27; 11:1-2, $7)$. This 'faith Israel' is symbolised by the olive tree in Romans 11:17-24, into which Gentiles have been grafted.

In Romans Paul consistently internalised his Judean/Israelite ethnicity in personal self-identification, yet it is an identity for which he has drawn new boundaries and given new content. This 'Israel' to whom Paul belongs is described in terms similar to those encountered in his other letters: 'body of Messiah' (Rom 12:5); 'seed of Abraham', who is 'the father of us all' (Rom 4:16); 'children of promise' (Rom 9:7-9); 'sons of God' (Rom 8:14-16, $19 ; 9: 26)$. Believers belong to the Lord (Rom 10:9; 14:8-9), and are the 'chosen/elect' and the 'called' (Rom 8:28, 30, 33; 9:24; 11:7).

The evaluative dimension comes next, and is particularly important for our investigation. Part of people's attachment to an ethnic group is that group members desire a positive valuation of their own group which can be compared favourably with others (Esler 1996; 1998:42-48; Horowitz 1985:143-147). This is no less true of Israelites. They were socialised into a world of divine favour and covenantal privileges, and, just like other peoples, made claims of superiority in character, values, intelligence and beliefs (Gruen 2002).

How does Paul compare? It is clear from Paul's writings that claims of divine favour and privilege are no longer exclusively applicable to Israel, and he undermines the notion of Israelite superiority vis-à-vis the Gentiles in various ways. A new map of persons is available now that define members of God's covenant people (Neyrey 1990:66-68). ${ }^{7}$ The followers of the Messiah can claim that privileged identity called 'righteousness' (Gal 2:21; $3: 6$, etc.), something evidently offered by Paul's opponents to the Galatians and within reach if the latter were to become part of the dominant Israelite group (Esler 1998:154-55, 169, etc.; Nanos 2002a:80, 102, etc.). The Jesus followers are the 'holy ones', the ones 'washed ... sanctified ... justified' (1 Cor 6:11). They can also claim the title 'sons' of God/Abraham, being no longer 'slaves', and therefore entitled to an inheritance (Gal 3-4).

In contrast, Paul speaks of the city of Jerusalem as in slavery with her children. Paul contrasts this with the Jerusalem that is 'above', who is free, 'and she is our mother' (Gal 4:25). He also stereotypes unbelieving Israelites as those whose minds are dull, still being under a veil when the 'old covenant/Moses' is read (2 Cor 3:14). They belong to those who are 'perishing', their minds

7.Gal 3:28; 5:6; 6:15; 1 Cor 1:18, 24; 7:19; 12:13; cf. Col 3:11; Eph 2:12; 3:6 
being blinded by the god of this age (2 Cor 4:3-4). They are still under the 'curse' of the Law (Gal 3:10,13), what Esler (1998:185) describes as a rigid and extreme form of stereotyping.

Esler $(1996 ; 1998: 215-34)$ has also argued that Galatians 5:13-6:10 does not move away from the issue of pressure being exerted on Gentile believers to live according to Judean Law. Paul argues against claims of 'Judaism' being a superior form of identity, and his aim is to create an identity distinct from Judean and Gentile. In the process he inverts the values of the synagogue/'Judaism' (i.e. being a sinless community) by stigmatising the world outside of the congregations as belonging to the realm of 'flesh' ( $\sigma \alpha \dot{\alpha} \xi)$, as opposed to the Spirit-conditioned life within the congregations (Esler 1996:231). Theirs is the right identity and true positive values, as outlined also by the fruits of the Holy Spirit (Gal 5:2223). Overall they must conduct themselves in a way appropriate to family members and not engage in honour contests.

Further negative valuations of Judeanness are found in Philippians and 2 Corinthians. Paul internalises his Israelite ethnicity in self-identification for rhetorical purposes, but later dismisses it as irrelevant. In 2 Corinthians 11:22 he defends himself against what appears to be Israelite 'super-envoys', using the rhetorical strategies of self-praise (boasting) and comparison. Paul writes: 'Are they Hebrews? So am I. Are they Israelites? So am I. Are they Abraham's seed? So am I'. In this ethnic selfdefence, Paul is claiming equivalence. Being a Hebrew, an Israelite, and Abraham's descendant, he is like the super-envoys (Duling 2006). However, Paul also writes there is nothing to be gained by it (2 Cor 12:1).

We find a similar situation in Philippians 3:5-6 where Paul writes about Israelites who place great confidence 'in the flesh' (verses 3-4). Paul is also able to boast, as his Israelite honour was beyond reproach. Yet Paul turns around and says 'whatever gain I had I now consider loss for the sake of Messiah', even stating 'I consider them as rubbish' (Phil 3:7-8). So much for Judean/ Israelite honour! Contrary to the advice of Ben Sirach $(10: 19,24)$, for whom honour was found in obedience to the Torah and in following the values of Israelite culture, for Paul honour comes by following the crucified Messiah and as a divine gift, and no longer by following the Judean way of life (cf. Gal 1:14) (Jewett 2003).

Overall Paul has virtually destroyed Israelite claims of special privilege and superiority. It is also in this sense that Paul attacks Israelite 'boasting' (Gal 6:13-14; 2 Cor 11-12). Duling suggests that Paul's ethnic identity was only the beginning of his selfidentity. A change had occurred when he was 'recruited' to 'Christianity'. In Duling's own words:

I would argue that Paul believed that he had entered another ethnos, which had its own boundaries, its own values, and its own symbols. This ethnos, however, was not specified as rooted in genos from Israel, the phylē of Benjamin, the Hebrew language and culture, the norms of Torah, and the rite of circumcision. It was a different kind of ethnos. This was the true genos from Abraham, a sōma of the new life of Christ, a more inclusive language and culture, the norms of a different kind of gnōsis, the model of suffering slavery, and the rite of baptism. This was a new family.

(Duling 2008:814)

Duling's view is essentially sound, and we can relate it to Paul's language of 'newness'. To begin with, Paul can speak of his

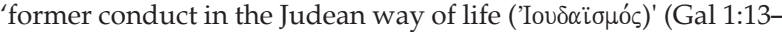
14), which probably came about by being 'crucified' to the world (Gal 6:14). Paul can forget what is behind him and strain towards that which is ahead (Phil 3:13). Paul and his Jesus followers participate in the 'new covenant' (1 Cor 11:25; 2 Cor 3:6).

This 'newness' is inextricably linked with being incorporated into the death and resurrection of the Messiah (cf. Ridderbos 1975:59 $60,207-208,403) .{ }^{8}$ Believers have entered a new ontological reality and gained a share in the Messiah's being, which produces 'Messiah in us', the 'new man'9 (cf. Wikenhauser 1960:32). Paul can say: 'I no longer live, but Messiah lives in me' (Gal 2:20).

In effect, the identity of the individual is totally Messiah orientated, to the new Adam, who is glorious (1 Cor 15:20-22 45-49; 2 Cor 4:4, 6; cf. Col 1:15, 18), and believers are being transformed into his image or glorious body (1 Cor 15:49; 2 Cor 3:18; 5:16-17; Phil 3:21; Gal 6:15). The combination of Paul's Christology and his transformation language suggests that he conceives of himself and his congregations as already expressing, or in the process of becoming, an identity that participates in the divine nature of God and so transcends the usual ethnic categories.

Having died with the Messiah, believers should walk/serve in the newness of the Spirit (of God/Messiah) or in the newness of life, and not in the oldness of the letter/the Law, for the Spirit gives life (Gal 5:18; 2 Cor 3:6). Paul himself was engaging in 'incessant boundary making', setting out two mutually exclusive ways of serving God (cf. Neyrey 1990:190-91). Paul consistently argued that the way through Messiah, and belonging to his community, was the superior and, indeed, the only way of serving God. One therefore cannot agree with Nanos (2002a:83-85, 100, 282) that Paul does not 'denigrate' or regard as 'inferior' Israelite identity. He does, not simply for its own sake, but in a context of Israelite unbelief and a sense of privilege and superiority.

In Romans Paul subverts Israelite identity on the one hand, while on the other maintains the privileges and status connected to it. Firstly, Paul is again trying to create a positive identity for the Jesus followers in Rome vis-à-vis the synagogue. Similar to Gal 5:13-6:10, in Romans 12:1-15:13 Paul covers the norms or 'identity descriptors' (especially agape) necessary for the maintenance and enhancement of their identity (Esler 2003c:55). Paul's language of 'newness' also appears again (Rom 6:2-4, 6; 7:6; 8:4, 9; 13:14). As in Galatians, Paul constantly wages an ideological warfare between the 'old' Mosaic era versus the 'new' life in the Spirit (Hubbard 2002).

But what about the status of Israel and their relationship with the new movement that emerged around the figure of Jesus the Messiah? Here we find Paul's exposition of God's dealings with creation, his righteousness (faithfulness), as well as his impartiality, important themes that relate to the evaluative dimension of having Israelite identity and membership.

Let us begin by examining Paul and the question of theodicy. Because most of Israel has rejected the gospel, is God righteous? Is he faithful to Israel? This is a question that Paul poses in Rom 3:5; 3:25-26; 9:6a (Byrne 2001:234-35). Paul's answer is 'yes', and it is important to him to maintain the priority of the Israelite in the gospel. The 'righteousness of God' appears in Romans repeatedly (e.g. Rom 1:17; 3:5, 21, 22, 25, 26; 10:3) and it has to do with God's faithfulness and the fulfilment of his promises to Israel: 'first for the Judean ...' (Rom 1:16; 2:9-10) (cf. Beker 1986:16). Linked with Israel's priority is Paul's argument for the equality of Israelite and Gentile: '... also for the Hellene' (Rom 1:16; 2:9-10; cf. Rom 11:26-32) (cf. Beker 1986:14-15). God is, therefore, not faithful only to Israel, but to humanity as a whole. In this regard God's giving of the Spirit (Rom 1:16-17; 8:9-11), forgiveness (Rom 3:25-26), and the story of Abraham (Rom 4; 9-11), and the Davidic kingship of Jesus (Rom 1:3-4; 15:12), has universal significance (Byrne 2001; Whitsett 2000).

Intermingled with this universal significance of God's Messiah is Paul's argument for God's impartiality, a central theme to all of chapters 1-3 (see especially Rom 2:11; 3:22, 29). God has judged all people to be sinners, be they with or without the Law. At the same time, God provides exactly the same means of salvation, for 'all who believe' (Rom 3:22; 4:11; 10:4). This theme of 'all' is

8.Gal 2:19-20: 1 Cor 12:13: 2 Cor 5:14; cf. Col 2:20

9.cf. Eph $2 \cdot 15 \cdot 4 \cdot 22-24$. Col 2:12-13: 3.9-10. 
quite consistent throughout Romans (Rom 10:12; 11:32). Simply put, in every aspect of judgement and accountability, as well as the means and availability of salvation, God treats Israelites and Gentiles as equals (Bassler 1984).

It should come as no surprise that Paul asked the following question: 'What advantage, then, is there in being a Judean, or what value is there in circumcision?' (Rom 3:1). 'Much in every way', Paul responds (Rom 3:2; cf. 2:18-20). However, the overall logic of Paul's argument is that whatever advantage the Judeans think they have, it is now something of the past, or alternatively, an illusion. Instead of elevating Judean identity to a privileged position, Paul reduces it to a level where it shares the common plight of humanity having inherited the disobedience and sinfulness of Adam (Rom 3:23; 5:12, 19). That is why Paul also questions Israelite 'boasting' once again (Rom 2:17, 23), i.e. any claims to a chosen and privileged status, honour or confidence in their identity as Israelites, and as members of the covenant people (Dunn 2008:9, 129 etc.; Jewett 2003).

To add insult to injury, Israel is a disobedient and stubborn people (Rom 10:21). Paul admits they are zealous for God, but their 'zeal is not based on knowledge' (Rom 10:1). However, God has not rejected his people; there is a remnant of Israel, 'the elect', who were chosen by grace (Rom 11:1,5), while the others were hardened (Rom 9:27; 11:1-2, 7). Paul and fellow Judean believers are part of the olive tree (faith Israel) from which unbelieving Judeans, at least for the moment, has been removed. That brings us to another dimension of Paul's attitude towards ethnic Israel.

From the above we may conclude that Paul's approach to ethnic Israel - who for the greater part has rejected the gospel - is that they have lost any claim to the privileges they once had, and that he totally rejects their self-perceived superiority. However, Paul's discourse on ethnic Israel in Rom 9-11 does not allow for such a sweeping conclusion. Here the emotional dimension of group identity and membership also comes into play. For example, in the allegory of the olive tree (Rom 11:17-24), nonIsraelites - likened to wild branches which cannot produce edible fruit - are represented as grafted into Israel, a cultivated olive tree. They are attached in a way that Paul describes as

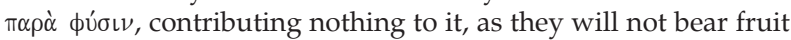
and are in fact 'parasitic upon its richness' (Esler 2003b:124). The implication is that, to the contrary, if the natural branches were to be grafted back, they would bear more fruit. So where Paul 'denigrates' Israelite identity within the context of unbelief, he glorifies and even regards it as inherently 'superior' if all Israelites should show faith. What Paul writes about here was in response to non-Judean arrogance towards Israel among believers in Rome ( $c f$. Rom 11:13, 18, 20). Esler explains that Paul spent his career arguing that the Mosaic Law was not necessary for non-Israelites.

Yet this did not mean that he had forgotten his primary socialization as an Israelite, or that his work with non-Israelites had led him to abandon his pride in his Israelite ethnicity ... [When pushed Paul will] suddenly allow a long submerged aspect of his self to become salient in a passionate expression of his original affiliations of kinship and ethnicity.

(Esler 2003b:134)

Paul's positive valuation of Israel, however, extends even further. In Romans 11:1 and 1:5 Paul spoke of the chosen remnant within Israel. This may give the impression that unbelieving Israel stands under certain condemnation. However, this is not the case. Ethnic Israel's predicament is not final (Rom 11:11-32). From a redemptive-historical perspective their election overall still stands (Rom 11:28-29). From Romans 11:27 (quoting Isa $59: 20,21)$ and the context in which this is placed, one may assume that a covenant relationship still exists between God and ethnic Israel. What this translates to is Paul's astonishing claim that ethnic Israel, the extent of which will not be speculated on here, is assured eschatological salvation! The blindness that has come upon Israel is temporary, 'until the fullness of the Gentiles has come in' (Rom 11:25). ${ }^{10}$ Moreover, Paul specifically takes the view that it is God's redemptive action and not Israel's repentance, nor the Gentile mission, nor any human agency, that will initiate Israel's salvation (Baker 2005:482-483).

Paul's language also appears to suggest that Israel's reversal presumably through their acceptance of Messiah Jesus - will precede the eschatological age, will trigger the resurrection and coincide with the parousia (Rom 11:11-12; 15) (Donaldson 1993:93). Paul's positive valuation of God's continual commitment to ethnic Israel and their inherent potential when accepting the gospel makes it impossible for Paul to leave traditional Israel out in the cold. What advantage is there to being a Judean? Much more than the direct answer that Paul gave in Rom 3:2!

The emotional dimension that deals with attitudes towards 'outsiders' and 'insiders' also needs attention. Paul was socialised into a collectivist culture (Malina 1993; Malina and Neyrey 1996), and social behaviour in such a context tends to be dependent, emotionally attached and involved in the collective. It is also cooperative and self-sacrificing towards in-group members, but indifferent and even hostile to out-group members (Triandis 1994a:287). We have already seen that Paul encouraged conduct among believers that is appropriate to family members. On the one hand, this demonstrates his dedication to and concern for the congregations. On the other hand, and in the light of the above analysis, Paul would seem to be rather indifferent to Israelites, the ones that were traditionally part of his in-group (see 1 Thess 2:14-16; 1 Cor 4:12; 11:26; 16:22; 2 Cor 4:9; 11:26). Five times he received 'forty lashes minus one' (2 Cor 11:24). 'Punishment implies inclusion' Sanders (1983:192) maintains, yet it also implies that Paul knew he did not belong, and indeed, felt no need to belong as Israelites thought he should. Paul does not deem it necessary to be a 'people pleaser' (Gal 1:10) (Hubbard 2002:192-93). Thus Paul rejects the role of categorisation in that he rejects being told who he is (an Israelite) and what that means in terms of appropriate behaviour, honour and self-esteem. Paul is clearly not much of a dyadic or group-orientated person as far as his ethnic Israelite identity is concerned, for he does not live out the expectations of fellow Israelites. This means that the contention of Malina and Neyrey (1996:203) that Paul represented himself as the quintessential group-orientated person is in need of modification. Even so, there can be little doubt that Paul always remained emotionally attached to ethnic Israel (cf. Rom 9:2-3).

Paul's indifference also occasionally extended to Israelite Jesus followers, especially those who wanted to impose the Judean way of life on the Gentiles (2 Cor 11:2-3; 13-15; Gal 1:8-9; 3:1; $5: 12$ ). Moreover, Paul demonstrated a lack of cooperation, as he refused to withdraw from having table fellowship with Gentiles and for them to be circumcised (Gal 2). Even so, Paul's dependence, involvement and emotional attachment to the Israelite Jesus followers are evident in his mentioning of his visit to Jerusalem, where the reputed 'pillars' gave him the right hand of fellowship (Gal 2:9), and in his continual efforts to raise a collection for the poor in Jerusalem (Gal 2:10; 1 Cor 16:1; 2 Cor 8-9).

When we turn our attention to Romans, Paul wants to encourage a united community of Israelites and Gentiles, and to restore what appears to be a somewhat broken relationship between the two groups (Miller 2001; Beker 1986:11-12). In Rom 12:1-13:10 Paul again uses 'sibling language'. Taking into consideration that the sibling relationship was a central feature in antiquity and entailed reciprocity among family members, Paul again adopted this powerful frame of reference to guide behaviour. In other words, believers should act in a way normally expected of siblings (Taylor 2005).

10. Here Paul also reverses if not abandons the traditional eschatological scheme. The Gentiles will not gather to Zion as a consequence of Israel being saved. Rather, Israel will be saved after the completion of the Gentile mission (cf. Sanders 1983:195; and the counterview of Donaldson 1993:92). As Donaldson notes, Paul does not cite pilgrimage texts. 
According to Esler, in an attempt to reduce ethnic tension and conflict between Judean and non-Judean believers, Paul wants all persons concerned to internalise that they belong to a new group in Christ. Through their faith in Christ they have been recategorised and now have a common in-group (or superordinate) identity. Yet this

includes the recognition that an attempt at recategorisation ... is more likely to succeed if its proponent acknowledges the continued existence of the identities of the subgroups and modulates the message to attend to their distinctive outlooks and interests.

(Esler 2003c:54; cf. 2003a)

Paul, therefore, attempts to create 'unity in diversity' (Beker 1986:13), and believers are encouraged to accept one another and to praise God together (Rom 15:7, 9-12). We also need to pay attention to a person's emotional repertoire when influenced by his or her socialisation in a collectivist society. In collectivist cultures emotions focus not so much on the self (individual, private internal attributes), but more on others, i.e. they are 'other-focussed'. Emotions are experienced particularly in the presence of others, i.e. relationally and interpersonally. Negative feelings result when the relationship with the collective is seen to have come to an end, leading to ostracism, a major calamity in collectivist societies (Triandis 1994a; 1994b:168, 178-179). Collectivist societies are high in uncertainty avoidance and dislike surprising or con-conformist behaviour. So negative emotions are experienced when social behaviour is deviant or inappropriate (Triandis 1994a:293).

Paul's negative emotions, caused by his frustrated relationship with ethnic Israel, were likewise rooted in 'deviant' behaviour (Rom 15:30). He writes: I have great sorrow and unceasing anguish in my heart. For I could wish that I myself were cursed and cut off from Messiah for the sake of my brothers (Rom 9:2-3). This passage testifies to the broken relationship that Paul felt, but also to his strong concern and yearning for the salvation of his ethnic kinsmen. Paul also uses the motif of jealousy ( $\pi \alpha \rho \alpha \zeta \eta \lambda$ o $^{2}$ in Rom 10:19; 11:11, 14), which Esler (2003b:107-8) interprets to mean 'provoke to passionate concern for what is rightfully one's own'. In Romans, therefore, Paul appears to internalise his Israelite identity in a special, if not contradictory way. Contrary to Paul's harsh language in most of his letters, in Romans he expresses special fondness for ethnic Israel. There is evidently a sense of belonging on Paul's part. To be even more precise, Paul wants to belong (Rom 9:2-3), or Paul wants ethnic Israel to belong with/to him. And there is hope yet (at least in Romans) that a feeling of mutual belongingness will be restored.

\section{How much did Paul share in the 'Judean way of life', the Israelite cultural tradition, or its aspects of shared meaning?}

We will proceed to investigate this question by breaking it up into two sections, namely Paul and Israel's core values, and Paul and Israel's cultural institutions. According to Barth (1969), some cultural features function as emblems of ethnic distinctiveness, while others are played down or even ignored. Broadly speaking, the cultural features that serve the purpose of ethnic differentiation can be divided into two categories. Esler summarises the approach of Barth as follows:

First, there are overt signals or signs, features which people deliberately adopt to show identity (for example, dress, language, architecture and lifestyle). Second, there are basic value orientations, the norms of morality and excellence used to assess performance.

(Esler 1998:80)

The second feature plays an important role in identity:

Since belonging to an ethnic category implies being a certain kind of person, having that basic identity, it also implies a claim to be judged, and to judge oneself, by those standards that are relevant to that identity.

(Barth 1969:14)
We will focus on Paul's approach to these 'standards' or 'basic value orientations' next.

\section{Paul and Israel's core values ('sacred canopy')}

First attention needs to be drawn to what is understood here as Israel's norms or core values, at least as far as they relate to ethnic identity. There is of course (1) faith or loyalty to the God of Israel (Yahweh), the monotheism it implies and the avoidance of idolatry. Then there is (2) Israel's understanding of being a divinely elected people, chosen from all the peoples of the world by God to be his special possession. With this understanding went a sense of honour and privilege. Born out of this election is (3) Israel's understanding of having a covenant relationship with God, a covenant relationship which is maintained through (4) obedience to the Torah. All of these are related to (5) the notion of having a common ancestry derived from Abraham and the other patriarchs (the persons with whom Israel's covenant(s) was initially made). Connected to this is (6) a shared 'historical' tradition or memory. The last core value on the list is (7) Israel's millennialism, i.e. the hope for the restoration of Israel. These core values were the main focus points of orientation for action in everyday life ( $c f$. Pilch and Malina 1993:xiii). They relate to the rules of acceptable attitudes and behaviour necessary by Israelites in order for them to communicate group identity ( $c f$. Esler 2003c:54; Tajfel 1981; Brown 2001). The above core values correspond to what I have described elsewhere as elements of Israel's 'sacred canopy' (Cromhout 2007:105-106).

Being socialised into a collectivist culture, the views, needs and goals of Israel would normally have been the most important not so much that of the individual, Paul (cf. Gal 1:14). Also emphasised in collectivist cultures are shared beliefs, those things which the individual and collective have in common (Triandis 1994a:287; cf. 1994b:167-72). In addition, ethnicity - a collectivist phenomenon - is a social identity that is primarily, but not exclusively, orientated towards the past. Enculturation and socialisation have as their aim for members to embody the traditions of their ancestors (cf. De Vos 1975:17-19; Malina and Neyrey 1996:166). How does Paul compare?

In many respects Paul's value system is consistently and deeply rooted in the God of Israel and the traditions of the Tanak (e.g. 1 Cor 10:11). Salvation is only rooted in Israel. In this regard Paul has specifically been chosen by the God of Israel and/or the Messiah as an envoy of the Gospel (Gal 1:1, 15; 2:7-8; Rom 1:1; 11:13; 15:16; cf. Eph 3:8). From Paul's perspective, therefore, he embodied the traditions of his ancestors. He remains faithful to Israel's God (1 Thess 1:9; 1 Cor 8:6; Rom 11:36). At the same time Paul argues for God's freedom to do as he wishes through Jesus and to create a new divine (dis)order, even if it contradicts the previous ways of the synagogue and Temple (Neyrey 1990:5865). Paul's understanding of the Gospel therefore brought about a value system different from the traditional 'Judean way of life' which most Israelites - who for the greater part took their ethnic identity seriously - rejected. Let us first look at Paul's approach to Israel's divine election and covenant.

\section{Paul and Israel's divine election and covenant}

The core value of divine election traditionally required Israelites to foster a strong sense of distinctiveness from the Gentiles. Differently put, divine election (along with the other core values) required the communication of cultural difference in opposition to others (see further below). However, it is evident from the above that for Paul the notion of divine election was no longer exclusively applicable to Israel. A new map of persons came into being that defined members of God's covenant people (Neyrey 1990:66-68). Instead of being in a privileged position, Paul reduced Israelite identity to a sharing of the common plight of humanity (Rom 3:23; 5:12; 5:19). 'In Adam all die' (1 Cor 15:22). They seemingly also share the state of anthropological nakedness (1 Cor 15:37; 2 Cor 5:3), thus a state of shame (cf. Neyrey 1993). Paul in various ways, therefore, subverts Israel's special 
covenant status. By his own admission Paul is a minister of the new covenant ( 2 Cor $3: 6 ; c f .1$ Cor 11:25). This is intimately connected with the faith covenant that God made with Abraham (Gal 3:15-18; cf. Gal 3:6). According to Hahn (2005), Galatians 3:15-18 has Genesis 22:15-18 as subtext and hermeneutical key, namely the covenant God made with Abraham and ratified by divine oath after the Aqedah. Here God promised to bless the nations through Abraham's 'seed'. Because this covenant carried both historical priority and theological primacy, the idea that obedience to the Mosaic Law was the necessary condition to fulfil the blessing to the Gentiles 'would be nonsense' (Hahn 2005:95). God did not add conditions (the Mosaic Law) to the Abrahamic covenant, which would be 'illegal' by human standards. And for ethnic Israelites themselves, the Mosaic covenant established at Sinai, which Paul equates with slavery, was only temporary, serving only 'until' the Seed will come (Gal 3:19-25; cf. Rom $4: 14 ; 7: 6 ; 10: 4 ; 2$ Cor 3:14-15). In Romans Paul writes of his own kinsmen 'according to the flesh' in the following way:

Theirs is the adoption as sons; theirs the divine glory, the covenants, the receiving of the Law, the temple worship and the promises. Theirs are the patriarchs, and from them according to the flesh came the Messiah...

(Rom 9:4-5)

This is Paul's commentary on the meaning of 'Israelite' (Duling 2006). One can even say that Paul gives us a small window into the Israelite symbolic universe. However, the description here assumes that Israel have lost these privileges, and the continuity between Israel and the new order in the Messiah seems to have been broken ( $c f$. Epp 1986), that is apart from those Israelites who have faith. Romans 11:26-29, however, demonstrates that in a peculiar sense Paul continues to share ethnic Israel's belief in their chosen and covenant status, which overshadows any privileges that ethnic Israel may have lost.

\section{Paul and the Torah}

The Torah was one of the focus areas of the covenant. Israel received it as God's privileged and chosen people, and it spells out how they should live. For this reason the Torah can be understood as the 'constitution' of Israelite ethnic identity. Studies on Paul and the Law are exhaustive and controversial (cf. Roetzel 1995), and they are as well known as they are filled with controversy. However, our focus here will be narrow considering the limited scope of this article. By his own admission Paul was a zealot for the Law (Gal 1:14). Moreover, Paul describes himself as a Pharisee, implying strict Torah observance. His 'zeal' was such that he persecuted the believing community, even going as far as stating that he was 'blameless' with regards to the righteousness of the Law (Phil 3:5-6). This also means that Paul shared the concern for Israel's 'set-apartness' from the Gentiles and the boundary set up by the Law, what Dunn (1990; 2008:12, 122) correctly describes as the social function of the Law.

Paul's encounter with Messiah altered this in a radical way and he attacked the Law on two closely interrelated fronts: (1) the Law as an inferior, ineffective and malevolent principle belonging to the old age; ${ }^{11}$ and (2) the function of the Law in terms of separating Israelite from Gentile. God sent his Son to 'redeem those under law' (Gal 4:5). The argument that being 'under the law' is the particular plight of Gentiles who try to observe the Law (Johnson Hodge 2005:284; she refers to Gal 3:23; $4: 5 ; 4: 21 ; 5: 18$; Rom 6:14, 15) cannot be supported, as Paul wrote he was 'not under the [Mosaic] law' (1 Cor 9:20; $c f$. Acts 21:21), but under Messiah's Law (1 Cor 9:21; Gal 6:2). The new covenant of which Paul is a minister is not one of the letter, but of the Spirit: 'for the letter kills, but the Spirit gives life' (2 Cor 3:6). This is the antithesis of Moses, who Paul caricatures as the 'ministry that brought death' (2 Cor 3:7). For Paul's opponents the works of the Law and the faith in/of Messiah (and his atoning death), were compatible and complimentary (Gal 2:16a). Paul, however, sets them as antithetical opposites (De Boer 2005; Esler 1998:122-

11.Gal 2:19-21; 3:10, 13, 19, 23-24; 4:9; 5:1; 1 Cor 15:56; Phil 3:9; Rom 3:20-21, $28 ; 6: 15 ; 7: 4,6$
23; Dunn 1990:195-96). 'Messiah is the end of the law', also in its boundary function, which separated Israelite and Gentile, in order that righteousness may become the possession of all who believe (Rom 10:4).

Paul's more 'theological' approach in Romans also indicates that the Law could not achieve its intended purpose. Although the Law is holy, righteous and good (is spiritual) it failed to give life. Moreover, it actually brought about death because of man's inherent disobedience and sinful nature (Rom 3:9-20; 7:10-12, $14,22-25 ; 8: 3)$. The function of the Law is that it gives knowledge of $\sin$ (Rom 3:20); 'it increases the trespasses' (Rom 5:20)! This is already hinted at in Galatians 5:3 and 3:10 where disobedience leads to being cursed.

What could complicate the investigation are Paul's words about the Law in other places: through faith, the Law is established (Rom 3:31); the Law can be summarised as the following commandment: 'Love your neighbour as yourself' (Gal 5:14; Rom 13:8-10), something that is of enduring significance. Does Paul still see the Torah in some respects as having a positive and continuing function, i.e. when it is 'denationalised' and no longer seen as the sole possession of Israel, or fixing a particular identity? Does it still reveal God's will and represent God's commandments ( $c f .1$ Cor 7:19), for example, as summed up in the love command (Dunn 2008:454-466)? Or is the choice simply between the Law and Messiah? The best the Law had to offer - love of one's neighbour - is obtained via something very different, namely the Spirit (Esler 1998:183-84, 204; 2003c:60). When Paul's statements about the (works of the) Law are viewed collectively, the second view is more persuasive.

This fact highlights the distance Paul had moved from his ethnic traditions in the cause of establishing a form of religion [a new ethnos? - MC] which can accurately be described as sectarian in relation to Israel.

(Esler 1998:183)

At the same time, it becomes near impossible to understand Paul's collective statements about the Law as a mere rhetorical device to discourage Gentiles to observe the Law, or that it does not reflect his own feelings on the matter ( $c f$. Gaston 1987; Stowers 1994; Gager 2000). In Romans 5-8 Paul negatively compares the Torah and Messiah using the first person plural (Rom $5: 1,8 ; 7: 5 ; 8: 4$ ) which must be a reference to Paul and his co-ethnics ( $c f$. Donaldson 2006:45-46). In other words, Paul's critique of the Law can also be applied to ethnic Israelites and their relationship to it.

\section{Paul and Israel's ancestry and shared 'historical' memories}

These two cultural features are treated together, as they are (for the greater part) closely interrelated in Paul's writings. To begin with, he can assert with confidence that he is a descendant of Abraham (2 Cor 11:22). In his overall scheme, however, Paul re-employs Abraham to become the ancestor of those who have faith (Gal 3:7-9, 26). Esler's (2006) investigation of Galatians 3 is instructive, especially how Paul approaches the figure of Abraham and how collective memory uses great figures from the past and is contested between groups. Here Esler rejects traditional interpretations of the text, as they do not take seriously the issue of Abrahamic descent itself. As Esler points out, Paul mentions Abraham 19 times, mainly in Romans and Galatians. Employing the insights of theories of ethnicity, social identity and collective memory, Esler understands that Abrahamic descent was a core feature to the ethnic identity of Judeans. For Paul's opponents to offer Abrahamic descent to the Galatian Gentiles was to offer an elevated status, which invoked various dimensions (the gift of the land, shared ancestry, a common culture, a sense of communal solidarity etc., all of which were in various ways derived from Abraham) of their identity.

It is this collective or cultural memory that is contested by Paul. In Galatians 3:6-29 Paul wants to demonstrate that it is those 
who have faith who are really the sons or seed of Abraham, not those who are circumcised (Israelite) as such (Gal 5:2, 12; 6:12). Esler argues that there:

is no suggestion here that Judeans outside the Christ-movement are also the sons of Abraham ... He has contested the memory of Abraham to such a degree as to remove Abrahamic descent entirely as an element in Judean [ethnic] identity and lodge it firmly in among the ranks of the [socio-religious] Christ followers of Galatia.

(Esler 2006:32)

At the same time Paul sees much value in the redemptivehistorical value of Abraham and faith Israel. He often cites from or alludes to the Tanak ( $c f$. Litwak 1998) and makes appeal to God's promises and his redemptive plan. Jesus, the Messiah of Israel, died for our sins, was buried and was raised 'according to the scriptures' (1 Cor 15:3). When the 'fullness of the time

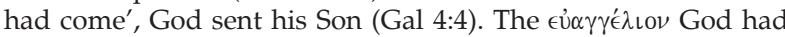
promised beforehand through his prophets and the scriptures (Rom 1:2). Messiah became a servant of the circumcision 'to confirm the promises made to the fathers' (Rom 15:8). Paul's call as an envoy (Gal 1:15-16) is described in similar terms to the call of Jeremiah (Jer 1:5 LXX) and Isaiah (Isa 49:1, 6 LXX). Jesus is a descendant of David (Rom 1:2-3; 15:12), the new Exodus (1 Cor 5:7; 19:1-4), 'our Passover' (1 Cor 5:7), and the story of Hagar and Sarah is used to establish a positive identity for his congregations (Gal 4:21-31). These are only a few examples, as Paul's various usages of Israel's history and traditions are too numerous to mention here. In most instances the past has only positive value when it points to Messiah. Paul is definitively more of a present- and future-orientated person. We do not find much nostalgic ethno-symbolism ${ }^{12}$ to maintain the status quo of traditional Israel and is basically limited to Romans 11, where Paul affirms God's covenant faithfulness and love to the Israelite people because of their 'fathers' / patriarchs (Rom 11:27-30).

\section{Paul and Israel's cultural institutions ('habitus')}

If core values are the focus points for the orientation of action, then institutions provide the way to realise them. 'Institutions mark the general boundaries within which certain qualities and directions of living must take place' (Pilch and Malina 1993:xv). For our purposes, we can interpret values as means to maintain Israelite ethnic identity or covenant status. The cultural 'institutions' discussed below correspond to what I have described elsewhere as components of Israel's habitus (cf. Cromhout 2007:100-105). They also broadly correspond to what Barth called the 'overt signals or signs' of ethnic identity. These include: (1) name - a corporate name that identifies the group; (2) land - the group has actual or symbolic attachment to an ancestral land; (3) language or local dialect; (4) kinship members of the group belong to family units, a local community or tribe, with the group as a national entity; (5) customs peculiar to that group; and (6) the group's religion.

In terms of name, we saw that Paul appropriates 'Israel' to be applicable to all followers of the Messiah, yet he can also apply it to traditional Israel. Paul shared with Israelites the tradition of speaking Aramaic (Acts 21:40; 22:2), perhaps Hebrew too (Phil 3:5), as well as Greek. However, in the first century language was not an important factor to share in Israel's cultural tradition. In terms of land (closely associated with the core value of millennialism), it is difficult to sustain arguments that Paul envisaged a restored Israel (pace Kaiser 1981). Cullman (1959:135) argued that Paul never allows Jesus's eschatological work to take on a 'political' form, i.e. as 'king of the Jews'. Paul writes of being called 'heavenward' in Messiah Jesus (Phil 3:14); 'our citizenship is in heaven' (Phil 3:20); the Jerusalem that is free is 'above' (Gal 4:26). Paul preaches a crucified Messiah, a stumbling block to Judeans (1 Cor 1:23), which probably reflects that the expected

12.Ethno-symbolism looks at an ethnic group's nostalgic perception of the past - expressed through cosmogonic myths, election myths, memories of a golden age symbols - and how it helps the group's ability to endure, but also to change and adapt (Duling 2005:127) millennial hopes were not realised by Paul's messiah. Paul's


probably suggests that a meeting with Messiah in the air will be followed by accompanying him back to earth ( $c f$. Brown 2000:53-55). If so, what then (cf. 1 Cor $4: 8 ; 6: 2-3)$ ?

The main issues confronting Paul in terms of 'institutions' were aspects of Israel's kinship, their religion and covenantal praxis (Judean customs). In terms of kinship, we saw that Paul had a frustrated sense of belonging to ethnic Israel (he wants to belong), and primarily saw himself as belonging to a new group (the 'body of Messiah' etc.), which constituted a new family or ethnos. Believers are encouraged to regard one another as family members and thus Paul attempted to establish a new kinship pattern that transcends the usual ethnic categories. Moreover Paul does not give explicit directions on the patriarchal family, which was a central kinship institution for Israelites in the first century. It may be significant that Paul does not mention his father in any of his correspondence. When it comes to marriage, Paul only addresses the issue of marriage between believers and non-believers and, in fact, says it is better not to get married (1 Cor 7), something quite contrary to the ethos of most Israelites. We may deduce that Paul was not pre-occupied with Israelites' producing progeny for the ancestors, or that he had a problem with 'mixed' marriages as opposed to the Israelite marriage strategy that was mainly endogamous (Hanson 1994:188).

In terms of religion and covenantal praxis, which are closely interrelated, everyday life for Israelites tapped into a rich repository of shared meaning and culture by which the Israelite symbolic universe was maintained. As the Torah was no longer an important core value to Paul, it should come as no surprise that, in contrast to the importance of covenantal praxis (which equates to Judean customs/Torah observance) for Israelites in general, this had become a matter of great indifference to Paul. ${ }^{13}$ A new map of time is available to Paul, where all time is of equal importance (Neyrey 1990:69). Sources of contamination are actions (1 Cor 11:27), the conscience, or the human will (1 Cor 8:7; Rom 14:14), and as such are subject to human control. This was in contrast to traditional Israelite understanding influenced by the priestly tradition that regarded impurity as an intrinsic property of objects and an inescapable part of life (EilbergSchwartz 1990:206)

The dominating factor in Paul's thinking is the unity of the community, social integration and mutual acceptance, socially enacted by the Lord's Supper (1 Cor 8:7-13; 10:14-32; 11:1734). Mixed table fellowship inevitably resulted in Paul and his Messianist movement being in a sectarian position to Israel, which did not really tolerate this practice (Esler 1994; 1998:12223).

Although Paul visited the Temple (Acts 21), the followers of Jesus are referred to as the 'temple of God' (1 Cor 3:16-17; 2 Cor $6: 16$ ) or the 'temple of the Holy Spirit' (1 Cor 6:19). This is a 'fluid space', as opposed to the fixed Temple in Jerusalem, because whenever and wherever the followers of Jesus meet they constitute a sacred space (Neyrey 1990:50). Sacrifice is also employed to refer to Messiah or the actions of his followers (e.g. 1 Thess 5:19-24; 1 Cor 5:7; Rom 12:1; 15:16). In the same vein forgiveness of sins is now bound to Jesus, and not the sacrificial cult in the Temple (Rom 3:24-25; 1 Cor 15:3, 57; cf. Col 1:14; Eph $1: 7)$.

In Romans we find a Paul that is similarly indifferent to 'works of the law' (Rom 2:28; 14:14, 20; cf. 1 Cor 8:7; 10:25). Paul actually refers to traditional covenantal praxis such as food laws and Sabbath observance as 'doubtful things' (Rom 14:1). ${ }^{14}$ It is

13.Gal 2:11-14; 4:10; 1 Cor 8:8; 10:25-28; 16:2; cf. Col 2:16

14. This makes the argument that Paul never disregarded dietary laws and basically remained Torah observant, and that his rhetoric merely refers to reprioritising aspects of his identity to live 'gentilelishly' (cf. Johnson Hodge 2005:278-79; Nanos 2002a; 2002b) unconvincing. This view also contradicts what Paul himself says in 1 Cor $9: 20$. 
significant that Paul can make this kind of statement in Romans, his most accommodating letter to the Judean way of life, and is an indication of the distance he moved away from critically important aspects of the Israelite cultural tradition.

At the same time, Paul was particularly lenient and accommodating to those who made a distinction between clean and unclean (Rom 14:1-15:11). In agreement with Barclay (1996), the terms 'strong' and 'weak' relate to the observance or nonobservance of the Torah. Paul refers to those who insist on Torah observance as 'the weak', but they need to be accommodated within the community. The argument of Nanos (1996:143) that the weak refers to 'those Jews who do not yet believe in Jesus as the Christ of Israel' has not found widespread support. Paul's overall instruction is that whether people eat, or not eat, observe days or regard all days as the same, that is all acceptable as long it is done to the honour of Messiah (Rom 14:5-9; cf. Gal 4:10).

Esler (2003b; 2003c) states that Paul's approach in Romans was probably due to negative reactions to his work in Galatia, where he was far less sensitive to Judean identity than in Romans, and he came to realise that he should not seek to erase the subgroup identities of Judeans and non-Judeans. However, Barclay (1996:212) also points out the difficulties in Paul's instructions in Romans. In agreement with Boyarin's (1994) view, he explains that Paul's 'tolerance' of cultural difference in fact turns out to be intolerant of those for who regarded the practice of their cultural traditions as at the very core of their identity. Paul ends up undermining the social and cultural integrity of the law-observant 'Christians' (Rom 14-15), because they are forced to acknowledge the equal validity of non-observance. By relativising cultural differences, Paul threatens the seriousness by which they are approached by their practitioners.

To conclude, when we look at Paul's general approach to religion and covenantal praxis, it is not that he was opposing mere external nomistic observance in the flesh or mere 'human religiosity', as contended by Hubbard (2002:193-94, 198, 211, 214). The matter runs much deeper. Paul uses primarily theological arguments to counter the primarily socio-cultural reality of rigorous attachment to an ethnic identity, to the exclusion of other ethnic groups. In other words, he opposed Israelite claims of special privilege before God and the idea that God's divine favour and saving purposes were restricted to the realm of Israelite ethnic identity. What Paul was opposing, it is submitted here, is what ethnicity theory describes as 'primordialism'. Primordialism is an anthropological category that attempts to explain how social actors themselves could experience their identity, i.e. to explain the emotional and psychological strength of ethnic affiliation, and takes into account the role of affect and socialisation (Fenton 2003:89). In some cases - particularly in a context where ethnic differentiation is prominent (cf. Jenkins 1997:47, 58-59) ${ }^{15}$ - ties of family, language, customs and religion and so forth are so powerful they can develop to be seen by social actors as 'natural', 'fixed', 'ineffable', 'involuntary' or 'sacred'; in other words, they are 'primordial' (Duling 2005:126). Paul himself expressed this reality as Israelites 'boasting in the flesh' (2 Cor 11:18; Gal 1:13), their own identity, or in terms of his own past life, his 'zeal' for the Judean way of life (Gal 1:14; Phil 3:6). Paul evidently moved beyond some vital aspects of shared meaning which made Israelites a distinctive ethnic group. In this sense for Paul to be an 'Israelite' has become an all-inclusive salvation concept with new content, with new aspects of shared meaning, and is no longer a socio-cultural identity with its own cultural tradition that should be seen as standing in opposition to ethnic out-groups.

15.Jenkins, however, avoids using the term 'primordial'. Where ethnic identity is sufficiently salient to be internalised during early primary socialisation, ethnicity can be characterised as a primary - not primordial - dimension of individual identity (Jenkins 1997:47)

\section{How did Paul communicate his ethnic identity (i.e. his similarity or difference)? Did he externalise his ethnicity in social interaction?}

Barclay (1996:209) has correctly pointed out that the 'bond which held Jews [here understood as "Judeans"] together was primarily social: their common life in observance of ancestral customs'. This has close affinity to Hall's description of ethnicity as a 'social activity' (Hall 1997:25). Their observance of ancestral customs was therefore nothing other than the communication of identity and the externalisation of their ethnic identity in social interaction. It communicated belonging and similarity vis-àvis co-ethnics and difference or 'distinctiveness' in opposition to ethnic outsiders. That is why Israel was defined more by orthopraxy than by orthodoxy (Cohen 1987:61, 103; $c f$. Schmidt 2001:25). In other words, doing (= communicating) was given greater prominence than having the right 'theology' or 'faith'. Josephus defines an apostate as a Judean who 'hates the customs of the Judeans' or 'does not abide by the ancestral customs' (War 7.50; Ant 20.100). He describes a convert as a Gentile who through circumcision 'adopts the ancestral customs of the Judeans' (Ant $20.17,41$ ), a sentiment also held by Philo (Virtues 102-108).

The House of Israel can be understood as a 'tight culture', where norms and values had to be followed more strictly. It can be associated with collectivist cultures where people are criticised for minor deviations from what is seen as proper behaviour, and where there are normally very strong feelings about the integrity of their in-group. Social behaviour is therefore a function of norms and duties imposed by the collective, and as already mentioned, is dependent, emotionally attached, and involved in the collective, as well as cooperative and selfsacrificing ( $c f$. Triandis 1994a:287; 1994b:159-72). A means to control behaviour is through shame, a more common emotion in collectivist cultures. 'Shame stimulates behaviour that leads to acceptance by the group, in addition to stimulating behaviour that flees group rejection; agreeing with the group norm is one of these behaviours' (Frijda \& Mesquita 1994:78). Therefore, in Paul's world, change was not generally seen as a good thing, and it questioned both the value of and loyalty to tradition. The culture of the time valued stability and constancy of character and compliance, as well as the willingness to conform one's actions to cultural standards. Adherence to the Law, customs and tradition was a matter of honour. At the heart of resistance to change was conformity to God's changeless law (Malina and Neyrey 1996:39; McVann 1993a; 1993b; cf. Berry et al. 2002:56-59).

Considering the above, we may gather from Paul's Israelite identity - after his encounter with the risen Messiah - that Paul did not communicate his similarity and/or difference very well, and indeed, made little effort to do so most of the time. He felt no need to make a good showing in the flesh (e.g. Gal 6:12-13), in other words to conform to cultural standards imposed by the collective. He turned the normal standards of honour and shame upside down. In his own words, no one will be declared righteous/be justified by observing the Law (Gal 2:15-16; Phil 3:9), i.e. no one will be declared righteous/be justified by communicating (privileged) Israelite identity. At times he chose to externalise traditional Israelite ethnicity in social interaction (cf. Acts $13: 14 ; 14: 1 ; 16: 3,13,16 ; 17: 1 ; 21$, etc.); at times he chose to suppress it, even to dismiss it entirely. Paul, in a famous passage to the Corinthians, wrote: 'I have become all things to all men' to win people for the Messiah. He became as one under the Law for Israelites (although he states that he himself is not under the Law) and became as one without the Law for Gentiles (1 Cor 9:20-22).

Paul's 'language of becoming' as an Israelite/Gentile can certainly be interpreted as Paul having multiple identities or having a flexible identity (Johnson Hodge 2005:283-84). At the same time, however, it can be understood that for Paul himself, being an ethnic Israelite (or Gentile) has largely become subordinate if not irrelevant. In the very least, it is no longer an absolute or indispensable measure of self-identification. When combined 
with Paul's language of newness, what people are now is either immaterial or a distant second to what they are in the process of becoming (Gal 6:15; 2 Cor 3:18; 5:17; Rom 8:29). Depending on a person's point of view, Paul either communicated/externalised deviance or inclusivity and the identity of belonging to a new order of being. The book of Romans illustrates that to be an 'Israelite' can also be an identity that is given new content in order to facilitate the inclusive nature of the believing community (Rom 15:7).

Overall, Paul's identity was certainly more 'fluid' than 'fixed' ( $c f$. par. 5 in the model). This also means that, from an etic perspective, Paul can be seen as Judean/Israelite ethnicity in reconstruction. Compared to his co-ethnics, Paul had much freedom through the gospel and genuinely exercised choice in line with the (re) constructionist approach of ethnicity theorists. ${ }^{16}$ That is, Paul was a different kind of Judean/Israelite or, in his own words, a Judean 'inwardly' (Rom 2:29). His ethnicity can also be seen as 'situational' (1 Cor 9:20-22), as his identity is expressed in different ways depending on changing social situations. There is a hint of primordialism as well, as illustrated in Romans 11.

This deviance and 'fluid' nature of Paul's identity was one of the reasons for him being hounded by his co-ethnics. He posed a threat to the integrity of the covenant people and for some Israelite Messianists must have been an embarrassment and a serious liability. They may have asked: How can we convince fellow Israelites about Jesus Messiah, while you, Paul, encourage the abandonment of our unique identity and welcome Gentiles as equals?

Following the 'interactionist' approach, Barclay (1995; 1999) states that deviance is essentially 'in the eye of the beholder'. Deviance is more of a social product, in that it is reacted to as deviant. Although in Israel there was widespread agreement on some aspects seen to incorporate deviant behaviour (e.g. idolatry and unclean food). Paul speaks of being endangered by his own countrymen (2 Cor 11:26), felt persecuted because of his view on circumcision (Gal 5:11), and received punishment from the Israelite assemblies (2 Cor 11:24). Even Israelite Messianists opposed him, as they regarded his eating with Gentiles as unacceptable (Gal 2:11-17). Paul is afraid of what will happen to him by those 'who do not believe' when he goes to Jerusalem (Rom 15:31). According to Luke, when Paul was in Jerusalem he was reproached, because many believers who were 'zealous for the law' heard he taught the Diaspora Judeans to 'turn away from Moses, telling them not to circumcise their children or live according to our customs' (Acts 21:21). In accordance with Barclay (1999:304): 'Inasmuch as he was viewed by his contemporary Jews as an apostate, he was (historically speaking) an apostate, and no amount of pleading about the Jewish elements in his theology or the diversity within first-century Judaism can mask or alter that reality.

Although Paul can - from an etic perspective - be interpreted as a (different kind of) Judean or Israelite, we must also do justice to his historical situation. The point is that if Paul was reacted to as deviant, he did not communicate his identity or externalise his ethnicity according to the acceptable standards of the day. He simply did not behave in the traditional Judean/ Israelite way, because he no longer regarded it as an absolute or indispensable requirement. It was an identity to be modified, or used or not used as required, to communicate inclusiveness and equality among believers.

16.This does not mean that traditional Israelites did not (re)construct their ethnicity or did not exercise a degree of 'choice'. They did, but there identity was not nearly as 'luid' and freety chosn' as that of Paul. Itwas mu 'pren viewed from this perpective it can also be said that Pauldid not participate with other Israelites in the social process of (re)constructing boundaries in opposition to Gentiles. Rather, he (re)constructed boundaries vis-à-vis both non-believing Israelites and Gentiles in service of the new ethnos he belonged to.

\section{CONCLUSION}

The underlying motivation of our investigation was to answer the question: Can we speak of Paul's former conduct in the 'Judean way of life' or not? What was Paul's position about this? It should be borne in mind that the 'Judean way of life' ('Judeanism') in its first-century context was an ethnic identity communicated by a select group of people ('Judeans/Israelites') in opposition to ethnic out-groups. Was Paul's statement in Galatians 1:13 a mere rhetorical flourish, an 'occasional' application, or could it be seen to ring true throughout his letters? The substance of our investigation led to the latter conclusion. What we found throughout Paul's letters - when we looked at them beyond their contingencies and considered both their consistencies and internal contradictions - was fundamentally the same Paul. Our investigation led us to the following insights:

If we work from the premise that Romans was a baseline or minimum standard for Paul's identity, his 'last will and testament' (Bornkamm 1977), Paul had a frustrated sense of belonging to Israel, he wanted to belong. He saw in his kinsmen according to the flesh both the inherent potential to produce more fruit, as well as the assured outcome of being saved. He continued to see himself as an Israelite, but who belonged to his 'Israel', which, at least for the moment, was radically transformed, with (mostly) Gentiles being grafted in and (mostly) traditional Israelites placed without. If Romans was actually a profoundly occasional letter (Beker 1986:11), then to pinpoint Paul's identity in that regard, that is, whether affirming or denying it, would remain an elusive aim, because the way Paul approached it was inherently contradictory. Alternatively, it was 'situational', as Paul constructed his identity in different ways depending on the needs of the day. At times, he was able to take pride in his Israelite ethnicity, at other times his ethnicity was subordinate or irrelevant. What he appeared to be doing was to dismiss his Israelite identity within the context of Israelite claims of exclusive privilege and superiority. On other occasions, he donned the Israelite robe when he spoke of God's faithfulness to Israel or when he attacked Gentile arrogance.

Overall, Paul was not much of a dyadic or group-orientated person as far as his ethnic identity was concerned, for he did not aim to be a 'people pleaser'. In other words, he did not live according to the expectations of his co-ethnics. What was evidently consistent throughout was that Paul saw himself as primarily belonging to a new family or ethnos, the body of the Messiah, distinct from ethnic Israel and the Gentiles. This ethnos (or fictive kinship) from his perspective required mutual love, acceptance and accommodation, a place where there would be no room for honour contests.

As far as Paul and Israel's cultural tradition was concerned, Paul saw himself as being faithful to the God of Israel and the tradition and heritage of the forefathers throughout, as continuing within the line of Israel's salvation history. Of particular importance were those aspects that lent themselves to universal application. Paul interpreted Israel's cultural memory and tradition in terms of creating a new divine (dis)order. At the same time, he consistently detached himself from aspects of the Israelite cultural tradition (the 'Judean way of life') that sustained Israelite privilege, superiority and social exclusiveness. 'Works of the law' especially belonged to the old order of things and were replaced by the age of the Spirit. The cultural tradition of Israel was thus transformed into a discourse of equality between Israelite and Gentile. All were free to participate as they were, all shared equal accountability before God, and all had equal opportunity for salvation through Messiah. All people had Abraham as an ancestor through faith, could be a new creation, and had a new life in the Spirit. Jesus was the solution to the universal human plight, and was not the religious, economic, social or political saviour of ethnic Israel exculsively. In this sense Jesus, the true Saviour, Lord and Son of God, was also the anti-type of Rome, its emperor and empire, and the value system it propagated (cf. Crossan and Reed 2004). 
Overall Paul utilised mainly theological arguments to counter the mainly socio-cultural reality of rigorous attachment to an ethnic identity, the Judean way of life, to the exclusion of ethnic 'others'. What Paul opposed was what ethnicity theorists describe as 'primordialism', that is, zeal for the law and the understanding that God's divine favour and saving purposes were restricted to the realm of Israelite ethnic identity. For the envoy, 'Israel' had become an all-inclusive salvation concept, and was no longer an identity that had to stand in opposition to ethnic out-groups.

We also discovered a consistent pattern of Paul communicating an identity of inclusiveness, where equality between Israelite and Gentile was made tangible in social reality. That was vividly externalised through Paul's seeing of himself as an envoy to the Gentiles, and him both encouraging and participating in mixed table fellowship in the Lord's Supper. According to Paul, no one would be saved by communicating (privileged) Israelite identity. Thus he was free to exercise choice and 'became all things to all men'. On the one hand that would appear somewhat spineless - especially to people who regarded their ethnic identity seriously - but on the other hand, and given the flexible nature of Paul's identity, that could be seen as a way of communicating inclusivity and a new order of being.

\section{REFERENCES}

Baker, M., 2005, 'Paul and the salvation of Israel: Paul's ministry, the motif of jealousy, and Israel's yes', Catholic Biblical Quarterly 67, 469-484.

Banks, M., 1996, Ethnicity: Anthropological Constructions, Routledge, New York.

Barclay, J.M.G., 1995, 'Deviance and apostasy. Some applications of deviance theory to first-century Judaism and Christianity', in P.F. Esler (ed.), Modelling early Christianity. Social-scientific studies of the New Testament, pp. 114-127, Routledge, London.

Barclay, J.M.G., 1996, 'Neither Jew nor Greek: Multiculturalism and the new perspective on Paul', in M.G. Brett (ed.), Ethnicity and the Bible, pp. 197-214, Biblical Interpretation Series 19, Brill Academic, Leiden.

Barclay, J.M.G., 1999, 'Deviance and apostasy. Some applications of deviance theory to first-century Judaism and Christianity', in D.G. Horrell (ed.), Social-scientific approaches to New Testament interpretation, pp. 289-307, T \& T Clark, Edinburgh.

Barth, F. (ed.), 1969, Ethnic groups and boundaries, Little \& Brown, Boston.

Bassler, J.M., 1984, 'Divine impartiality in Paul's letter to the Romans', Novum Testamentum 26(1), 43-58.

BDAG, 2000, A Greek-English Lexicon of the New Testament and other Early Christian literature, 3rd edn., University of Chicago Press, Chicago.

Beker, J.C., 1986, 'The faithfulness of God and the priority of Israel in Paul's letter to the Romans', Harvard Theological Review 79(1-3), 10-16.

Berry, J.W., Poortinga, Y.H., Segall, M.H. \& Dasen, P.R., 2002, Cross-cultural psychology. Research and applications, 2nd edn., Cambridge University Press, Cambridge.

Bornkamm, G., 1977, 'The Letter to the Romans as Paul's last will and testament', in K.P. Donfried (ed.), The Romans Debate, pp. 17-31, Augsburg, Minneapolis.

Boyarin, D., 1994, A Radical Jew: Paul and the Politics of Identity, University of California Press, Berkeley.

Brown, A.R. 2000. 'Paul and the parousia', in J.T. Carroll, A.R. Brown, C.J. Setzer \& J.S. Siker (eds.), The return of Jesus in early Christianity, pp. 47-76, Hendrickson Publishers, Peabody.

Brown, R., 2001, Group processes: Dynamics within and between groups, 2nd edn., Blackwell, Oxford.

Buell, D.K. \& Johnson Hodge, C., 2004, 'The politics of interpretation: The rhetoric of race and ethnicity in Paul', Journal of Biblical Literature 123(2), 235-251.
Byrne, B., 2001, 'Interpreting Romans Theologically in a Post"New Perspective" Perspective', Harvard Theological Review 94(3), 227-241.

Campbell, W.S., 2005, 'Perceptions of compatibility between Christianity and Judaism in Pauline interpretation', Biblical Interpretation 13(3), 298-316.

Cohen, S.J.D., 1987, From the Maccabees to the Mishnah, The Westminster Press, Philadelphia.

Cromhout, M., 2007, Jesus and identity. Reconstructing Judean ethnicity in Q. Matrix: The Bible in Mediterranean Context 2, Cascade Books, Eugene.

Crossan, J.D. \& Reed, J.L., 2004, In search of Paul. How Jesus's apostle opposed Rome's empire with God's kingdom, HarperCollins, New York.

Cullmann, O., 1959, The Christology of the New Testament, 2nd edn., transl. S.C. Guthrie \& C.A.M. Hall, The Westminster Press, Philadelphia.

De Boer, M.C., 2005, 'Paul's use and interpretation of a justification tradition in Galatians 2:15-21', Journal for the Study of the New Testament 28(2), 189-216.

De Vos, G., 1975, 'Ethnic pluralism: Conflict and accommodation', in G. De Vos \& L. Romanucci-Ross (eds.), Ethnic identity. Cultural continuities and change, pp. 5-41, Mayfield Publishing Company, Palo Alto.

Donaldson, T.L., 1993, "'Riches for the Gentiles" (Rom 11:12): Israel's rejection and Paul's Gentile mission', Journal of Biblical Literature 112(1), 81-98.

Donaldson, T.L., 2006, 'Jewish Christianity, Israel's stumbling and the Sonderweg reading of Paul', Journal for the Study of the New Testament 29(1), 27-54.

Duling, D.C., [2003] 2008, "“Whatever gain I had ...": Ethnicity and Paul's self-identification in Philippians 3:5-6', HTS Teologiese Studies/Theological Studies 64(2), 799-818.

Duling, D.C., 2005, 'Ethnicity, ethnocentrism, and the Matthean ethnos', Biblical Theology Bulletin 35(4), 125-143.

Duling, D.C., 2006, '2 Corinthians 11:22: Historical context, rhetoric, and ethnicity', in J. Fotopoulos (ed.), The New Testament and early Christian literature in Greco-Roman Context: Studies in honor of David E Aune, pp. 65-91, Supplements to Novum Testamentum, Brill, Leiden.

Dunn, J.D.G., 1990, Jesus, Paul and the law: Studies in Mark and Galatians, Westminster John Knox, Louisville.

Dunn, J.D.G., 2008, The New Perspective on Paul, Eerdmans, Grand Rapids

Eilberg-Schwartz, H., 1990, The savage in Judaism: An anthropology of Israelite religion and ancient Judaism, Indiana University Press, Bloomington.

Eisenbaum, P., 2005, 'Paul, polemics, and the problem of essentialism', Biblical Interpretation 13(3), 224-238.

Elliott, J.H., 2007, 'Jesus the Israelite was neither a "Jew" nor a "Christian": On correcting misleading nomenclature', Journal for the Study of Historical Jesus 5(2), 119-154.

Epp, E.J., 1986, 'Jewish-Gentile Continuity in Paul: Torah and/ or Faith (Romans 9:1-5)', Harvard Theological Review 79(1-3), 80-90.

Esler, P.F., 1994, 'Sectarianism and the conflict at Antioch', in The first Christians in their social worlds. Social-scientific approaches to New Testament interpretation, pp. 52-69, Routledge, New York.

Esler, P.F., 1996, 'Group boundaries and intergroup conflict in Galatians: A new reading of Galatians 5:13-6:10', in M.G. Brett (ed.), Ethnicity and the Bible, pp. 215-240, Biblical Interpretation Series 19, Brill, Leiden.

Esler, P.F., 1998, Galatians, Routledge, London.

Esler, P.F., 2003a, Conflict and identity in Romans: The social setting of Paul's letter, Fortress Press, Minneapolis.

Esler, P.F., 2003b, 'Ancient Oleiculture and Ethnic Differentiation: The Meaning of the Olive-Tree Image in Romans 11', Journal for the Study of the New Testament 26(1), 103-124.

Esler, P.F., 2003c, 'Social identity, the Virtues, and the Good Life: A new approach to Romans 12:1-15:13', Biblical Theology Bulletin 33(2), 51-63. 
Esler, P.F., 2006, 'Paul's Contestation of Israel's (Ethnic) Memory of Abraham in Galatians 3', Biblical Theology Bulletin 36(1), 23-33.

Fenton, S., 2003, Ethnicity, Polity Press, Cambridge.

Frijda, N.H. \& Mesquita, B., 1994, 'The social roles and functions of emotions', in S. Kitayama \& H.R. Markus (eds.), Emotion and culture. Empirical studies of mutual influence, pp. 51-88, American Psychological Association, Washington DC.

Gager, J., 2000, Reinventing Paul, Oxford University Press, Oxford.

Gaston, L., 1987, Paul and the Torah, University of British Columbia Press, Vancouver.

Gruen, E.S., 2002, Heritage and Hellenism: The reinvention of Jewish tradition, University of California Press, Berkeley.

Hall, J.M., 1997, Ethnic Identity in Greek antiquity, Cambridge University Press, Cambridge.

Hall, J.M., 2002, Hellenicity: Between ethnicity and culture, The University of Chicago Press, Chicago

Hahn, S.W., 2005, 'Covenant, Oath, and the Aqedah: $\Delta \iota \alpha \theta \eta \dot{\kappa}\rceil$ in Galatians 3:15-18', Catholic Biblical Quarterly 67, 79-100.

Hanson, K.C., 1994, 'BTB readers guide: Kinship', Biblical Theology Bulletin 24, 183-192.

Harris, M., 1976, 'History and significance of the emic/etic distinction', Annual Review of Anthropology 5, 329-350.

Horowitz, D.L., 1985, Ethnic groups in conflict, University of California Press, Berkeley.

Hubbard, M.V., 2002, New creation in Paul's letters and thought, Society for New Testament Studies Monograph Series 119, Cambridge University Press, Cambridge.

Jenkins, R., 1997, Rethinking ethnicity: Arguments and explorations, SAGE Publications, London.

Jewett, R., 2003, 'Paul, shame, and honor', in J.P. Sampley (ed.) Paul in the Greco-Roman world, pp. 551-574, Trinity Press International, Harrisburg.

hnson Hodge, C., 2005, 'Apostle to the Gentiles: Constructions of Paul's identity', Biblical Interpretation 13(3), 270-288.

Kaiser, W.C., 1981, 'The promised land: A biblical-historical view', Bibliotheca Sacra October-December, 302-313.

Litwak, K.D., 1998, 'Echoes of Scripture? A critical survey of recent works on Paul's use of the Old Testament', Currents in Research: Biblical Studies 6, 260-288.

MacDonald, M.Y., 1999, 'Ritual in Pauline churches', in D.G. Horrell (ed.), Social-scientific approaches to New Testament interpretation, pp. 233-247, T \& T Clark, Edinburgh.

Malina, B.J., 1993, The New Testament world. Insights from cultural anthropology, Westminster/John Knox Press, Louisville.

Malina, B.J. \& Neyrey, J.H., 1996, Portraits of Paul. An archaeology of ancient personality, Westminster John Knox Press, Louisville.

Martin, T.W., 2003, 'The covenant of circumcision (Genesis 17:9_ 14) and the situational antithesis in Galatians 3:28', Journal of Biblical Literature 122(1), 111-125.

McVann, M., 1993a, sv 'Change/Novelty Orientation', in J.J. Pilch \& B.J. Malina (eds.), Biblical social values and their meaning: A handbook, pp. 17-20, Hendrickson Publishers, Peabody.

McVann, M., 1993b, sv 'Compliance', in J.J. Pilch \& B.J. Malina (eds.), Biblical social values and their meaning: A handbook, pp. 31-33, Hendrickson Publishers, Peabody.

Miller, J.C., 2001, 'The Romans Debate: 1991-2001', Currents in Research: Biblical Studies 9, 306-349.

Miller, J.C., 2008, 'Ethnicity and the Hebrew Bible: Problems and prospects', Currents in Biblical Research 6(2), 170-213.

Nanos, M.D., 1996, The mystery of Romans: The Jewish context of Paul's letter, Fortress Press, Minneapolis.

Nanos, M.D., 2002a, The irony of Galatians: Paul's letter in firstcentury context, Fortress Press, Minneapolis.
Nanos, M.D., 2002b, 'What was at stake in Peter's 'Eating with Gentiles' at Antioch?', in M.D. Nanos (ed.), The Galatians Debate: Contemporary issues in rhetorical and historical interpretation, pp. 282-318, Hendrickson, Peabody.

Nanos, M.D., 2005, 'How inter-Christian approaches to Paul's rhetoric can perpetuate negative valuations of Jewishness - although proposing to avoid that outcome', Biblical Interpretation 13(3), 255-269.

Neyrey, J.H. 1990, Paul, in Other Words. A cultural reading of his letters, Westminster/John Knox Press, Louisville.

Neyrey, J.H., 1993, sv 'Nudity', in J.J. Pilch, B.J. Malina (eds.), Biblical social values and their meaning: A handbook, pp. 119125, Hendrickson Publishers, Peabody.

Pilch, J.J. \& Malina, B.J. (eds.), 1993, Biblical social values and their meaning: A handbook, Hendrickson Publishers, Peabody.

Ridderbos, H., 1975, Paul: An outline of his theology, transl. H.J.R. De Witt, Eerdmans, Grand Rapids.

Roetzel, C.J., 1995, 'Paul and the Law: Whence and wither?' Currents in Research: Biblical Studies 3, 249-275.

Sanders, E.P., 1983, Paul, the Law and the Jewish people, Fortress Press, Philadelphia.

Schmidt, F., 2001, How the temple thinks: Identity and social cohesion in Ancient Judaism, transl. J.E. Crowley, Sheffield Academic Press, Sheffield.

Scott, G.M., 1990, 'A resynthesis of the primordial and circumstantial approaches to ethnic group solidarity: towards and explanatory model', Ethnic and Racial Studies 13(2), 147-171.

Setzer, C., 2005, 'Does Paul need to be saved?', Biblical Interpretation 13(3), 289-297.

Smith, A.D., 1986, The ethnic origins of nations, Blackwell, Oxford.

Smith, A.D., 1997, 'Structure and persistence of ethnie', in M. Guibernau \& J. Rex (eds.), The ethnicity reader. Nationalism, multiculturalism and migration, pp. 27-33, Polity Press, Cambridge.

Stanley, C.D., 1996, "'Neither Jew nor Greek": Ethnic conflict in Graeco-Roman society', Journal for the Study of the New Testament 64, 101-124.

Stegemann, W., 2006, 'The emergence of God's new people: The beginnings of Christianity reconsidered', HTS Teologiese/ Theological Studies 62(1), 23-40.

Stowers, S.K., 1994, A rereading of Romans: Justice, Jews and Gentiles, Yale University Press, New Haven.

Tajfel, H., 1978, Differentiation between social groups: Studies in the social psychology of intergroup relations, Academic Press, London.

Tajfel, H., 1981, Human groups in social categories: Studies in social psychology, Cambridge University Press, Cambridge.

Taylor, W.F. 2002. s.v. 'Unity/Unity of Humanity', in D.N. Freedman (ed.), The Anchor Bible Dictionary, vol. 6, pp. 746753, Doubleday, New York

Taylor, W.F., 2005, Reciprocity, siblings, and Paul: Why act ethically?, Lutheran Theological Journal 39(2-3), 181-195.

Theissen, G., 1992, Social reality and the Early Christians: Theology, ethics, and the world of the New Testament, transl. M. Kohl, Fortess Press, Minneapolis.

Triandis, H.C., 1994a, Major cultural syndromes and emotion, in S. Kitayama \& H.R. Markus (eds.), Emotion and culture. Empirical studies of mutual influence, pp. 285-306, American Psychological Association, Washington DC.

Triandis, H.C., 1994b, Culture and social behaviour, McGraw-Hill, New York

Whitsett, C.G., 2000, 'Son of God, Seed of David: Paul's messianic exegesis in Romans 2:3-4', Journal of Biblical Literature 119(4), 661-681.

Wikenhauser, A., 1960, Pauline mysticism, Nelson, Freiburg. 